\title{
Cognitive changes in nurses working in intensive care units
}

\author{
Alterações cognitivas em enfermeiros que atuam em unidades de terapia intensiva \\ Alteraciones cognitivas en enfermeros actuantes en unidades de terapia intensiva
}

\section{Daniel Aragão Machado', Nébia Maria Almeida de Figueiredo', Luciane de Souza Velasques", Cleonice Alves de Melo Bento"I", Wiliam César Alves Machado', Lúcia Alves Marques Viannalv}

'Universidade Federal do Rio de Janeiro, Alfredo Pinto Nursing School, Postgraduate Program in Nursing and Biosciences. Rio de Janeiro, Brazil.

" Universidade Federal do Rio de Janeiro, Institute of Mathematics, Department of Quantitative Method. Rio de Janeiro, Brazil.

I"Universidade Federal do Rio de Janeiro, Center of Biological Sciences and Health, Department of Microbiology and Parasitology. Rio de Janeiro, Brazil.

" Universidade Federal do Rio de Janeiro, School of Nutrition, Laboratory of Nutrition and Chronic-Degenerative Diseases Investigation. Rio de Janeiro, Brazil.

How to cite this article:

Machado DA, Figueiredo NMA, Velasques LS, Bento CAM, Machado WCA, Vianna LAM. Cognitive changes in nurses working in intensive care units. Rev Bras Enferm [Internet]. 2018;71(1):73-9.

DOI: http://dx.doi.org/10.1590/0034-7167-2016-0513

Submission: 10-23-2016

Approval: 12-04-2016

\begin{abstract}
Objective: To measure the levels of stress, anxiety, and depression of nurses working in ICUs, relating them to levels of attention before and after 24 hours. Method: An observational, quantitative, analytical study with 18 nurses undergoing an inventory of stress, anxiety, and depression, as well as assessment of attention levels and psychomotor functioning. Results: Sixty-one percent showed positive for stress. Depression was observed in 33\%; and anxiety in 99.9\%. A strong correlation between stress and depression $(\rho=0.564$ with $p<0.05)$ and anxiety $(\rho=1$ with $p<0.05)$ was observed. There was a weak correlation between stress and task execution time in M2 $(\rho=0.055)$ for TMT A, a fact that did not occur in M0 $(\rho=-0.249)$. Conclusion: The study shows that the workload of the nurses working in 24-hour shifts in the ICU is correlated with high levels of stress, decreases in the attention process, and psychomotor decline. Descriptors: Nurses; Psychomotor Performance; Intensive Care Unit; Cognition; Nursing Care.
\end{abstract}

\section{RESUMO}

Objetivo: Medir os níveis de estresse, ansiedade, depressão dos enfermeiros que atuam em UTI, relacionando-os com os níveis de atenção do antes e após jornada de 24 horas. Método: Estudo observacional analítico, de abordagem quantitativa, realizado com 18 enfermeiros submetidos a um inventário de estresse, ansiedade e depressão, avaliação dos níveis de atenção e funcionamento psicomotor. Resultados: $61 \%$ possuem estresse positivo. Depressão foi verificada em $33 \%$; de ansiedade, em 99,9\%. Forte correlação entre estresse e depressão $(\rho=0,564$ com $p<0,05)$ e ansiedade $(\rho=1$ com $p<0,05)$. Correlação fraca entre estresse e o tempo de execução da tarefa em M2 $(\rho=0,055)$ para o TMT A, fato que não ocorreu em M0 $(\rho=-0,249)$. Conclusão: O estudo mostra que a carga trabalho dos enfermeiros que atuam em UTI, em turnos de 24 horas, está correlacionada com a elevação dos níveis de estresse, diminuição do processo de atenção e declínio psicomotor.

Descritores: Enfermeiros; Desempenho Psicomotor; Unidade de Terapia Intensiva. Cognição; Assistência de Enfermagem.

\section{RESUMEN}

Objetivo: Medir los niveles de estrés, ansiedad y depresión en enfermeros actuantes en UTI, relacionándolos con los niveles de atención anteriores y posteriores a jornada de 24 horas. Método: Estudio observacional, analítico, de abordaje cuantitativo, realizado con 18 enfermeros que completaron inventario de estrés, ansiedad y depresión; evaluación de niveles de atención y 
funcionamiento psicomotor. Resultados: 61\% sufre estrés positivo. Verificada depresión en 33\%; ansiedad en 99,9\%. Fuerte correlación entre estrés y depresión $(\rho=0,564$ con $p<0,05)$ y ansiedad $(\rho=1$ con $p<0,05)$. Correlación débil entre estrés y tiempo de ejecución de la tarea en M2 $(\rho=0,055)$ para el TMT A, hecho que no replicado en M0 $(\rho=-0,249)$. Conclusión: El estudio muestra que la carga laboral de los enfermeros actuantes en UTI en turnos de 24 horas está correlacionada con la elevación de los niveles de estrés, disminución del proceso de atención y declinación psicomotora.

Descriptores: Enfermero; Desempeño Psicomotor; Unidades de Cuidados Intensivos; Cognición; Atención de Enfermería.

\section{CORRESPONDING AUTHOR Willian César Alves Machado E-mail: wilmachado@uol.com.br}

\section{INTRODUCTION}

Cognitive function comprises mental processes associated with attention, perception, thought, learning, and memory, among others. Cognitive changes result in poor social interactions, and difficulty in working and carrying out selfcare activities. They interfere directly with the quality of life of individuals, and possibly also interfere with the quality of care provided by the nurse to the client ${ }^{(1-2)}$.

The term "stress" has been introduced from the areas of engineering and physics and has become popular in other areas because it is easily defined, manipulated, and measured. Stress can be defined as any situation of acute or chronic tension that produces a change in physical and emotional behavior, in addition to a psychophysiological adaptation response, which may be negative or positive ${ }^{(3-4)}$.

It is known that professionals of the nursing team, in order to perform their tasks, require concentration, and for that physical and psychological conditions should be in harmony. The level of stress they undergo during work hours becomes a predisposing factor for physical and psychological exhaustion ${ }^{(1,5)}$.

Depressive conditions have the power to reduce cognition. Stress directly affects interpersonal relationships, because irritability, anhedonia (loss of ability to feel pleasure), anxiety, and depression, present in more advanced cases, preclude full affective relationships and interfere with occupational relationships ${ }^{(5-6)}$.

Among all the environments where nurses provide care, studies differ as to which of these have a greater number of stressors. However, most show that closed environments, such as intensive care units (ICUs), have a great deal of stressors for nurses ${ }^{(7-8)}$.

Therefore, it is necessary to check the capacity of attention and psychomotor functioning (reaction time and speed of performance) during care of nurses who work in the ICU; to identify the effects of stress on the attention processes and psychomotor functioning of nurses working in ICUs; and to evidence whether there are differences in nurses' attention capacity and psychomotor functioning between when they begin and when they end their working day.

The relevance of this study is to investigate how the bodies of nursing professionals working in ICUs respond to the 24-hour workday. An example of this is the publication by the Brazilian Health Surveillance Agency (ANVISA) of Resolution RDC No 26 ${ }^{(9)}$ from May 11, 2012, which alters Resolution RDC No.
07 from February 24, 2010, and provides for the minimum requirements for the operation of intensive care units.

Thus, the objective of this study is to measure the levels of stress, anxiety, and depression of nurses working in an $I C U$, relating them to levels of attention before and after the 24-hour journey.

\section{METHOD}

\section{Ethical Aspects}

The protocol was initiated after approval by the Research Ethics Committee on September 20, 2011, and followed ResoIution no. 466/12 of the National Committee of Research Ethics (CONEP).

\section{Study design, setting, and period}

This is an analytical, observational, quantitative-based study that included nursing professionals who had work shifts of 24 hours, and evaluated them with a series of neuropsychological tests, consisting of an inventory of stress, anxiety, and depression.

The study scenario was an ICU of a private hospital located in the city of Rio de Janeiro, conducted from June to October 2013.

\section{Population or sample; inclusion and exclusion criteria}

The sample consisted of 18 nurses who worked and had a work shift of an uninterrupted 24 hours, either by exchange between professionals or due to an institutional need (previous requirement of the monthly work schedule, or immediate need of the service unit). Nurses who had a proven history of neurological and/or psychiatric disorders, and those with a history of excessive alcohol consumption and/or use of illicit drugs, were excluded.

\section{Study protocol}

\section{First Step $\rightarrow$ beginning of the 24-hour shift - MO}

Because the interpretation of the performances obtained in neuropsychological tests should consider some demographic variables, all subjects answered an Informational Questionnaire $(I Q)$ to characterize the sample.

Next, the LIPP Inventory of Stress Symptoms for Adults (LISS), the State-Trait Anxiety Inventory (STAI), and the Beck Depression Inventory (BDI) were delivered. These questionnaires were completed by participants during the work shift and given to the investigator at the end of the study participation ${ }^{(10)}$. 
After the delivery of the questionnaires, the nurses were invited to participate in the following neuropsychological tests: TAVIS (version 4.0), and Trail Making Test A and B. TAVIS is a computerized test that uses software to evaluate three aspects of attention (sustainability, selectivity, and alternation).

In TAVIS, stimulus-response time was recorded between the onset of the stimulus and the command by means of a joystick, with errors and successes from stimuli measured onscreen. Errors were classified into Action Errors (when responding to a wrong stimulus) and Omission Errors (when one fails to respond to a correct stimulus).

In the study population, only Task 03 was applied because it was closer to the proposed objectives. The option for Task 3 took place due to the need to understand how sustained attention in nurses can be influenced by a 24-hour shift.

Trail Making Tests A and B were used in the evaluation of subjects' motor skills, attention, and cognitive flexibility. We assessed sustained attention in part A, alternating attention and flexibility in part $\mathrm{B}^{(1,11)}$.

The tests were performed in a private environment, without external interference, in which the investigator and the subject had privacy for the application. The time of the tests was recorded with a stopwatch.

\section{Second Stage $\rightarrow$ end of 24-hour shift - M2}

Immediately after the 24 hours worked, the professionals underwent the same neuropsychological tests applied in Stage $\mathrm{MO}$ and returned the duly answered questionnaires.

The neuropsychological tests were evaluated through means, medians, standard deviations, and coefficients of variation between steps $\mathrm{M} 0$ and $\mathrm{M} 2$.

\section{Results analysis and statistics}

Data collected were allocated to an electronic worksheet available in the software PAWS Statistic 18. The Shapiro-Wilk Kolmogorov-Smirnov (KS test) and Wilcoxon test were applied for analysis of the neuropsychological tests applied. A p value of $<0.05$ was adopted for statistical significance.

\section{RESULTS}

The results obtained at the beginning and end of the 24-hour shift (a period from $7 \mathrm{am}$ to $7 \mathrm{am}$ of the following day, or from 7 pm to $7 \mathrm{pm}$ of the following day) were compared, which allowed checking the behavior of these elements in the period.

In the table below, the frequencies that characterize the study participants are described.

Regarding the time of rest on duty, although this practice was not established in the study scenario, $15(83.3 \%)$ nurses reported that they rest during the shift. Only two $(11.1 \%)$ nurses reported that they work 24 hours continuously; 13 $(72.2 \%)$ reported working 21 hours in a 24-hour shift. Only one professional $(5.5 \%)$ reported working 18 hours during a 24-hour shift, dedicating six hours to rest. Two participants $(11.1 \%)$ reported that they only rest for two hours when on duty, dedicating 22 hours to uninterrupted work in the intensive care unit.
Table 1 - Demographic Data - Nurses, Intensive Care Unit, Rio de Janeiro, Brazil, 2013

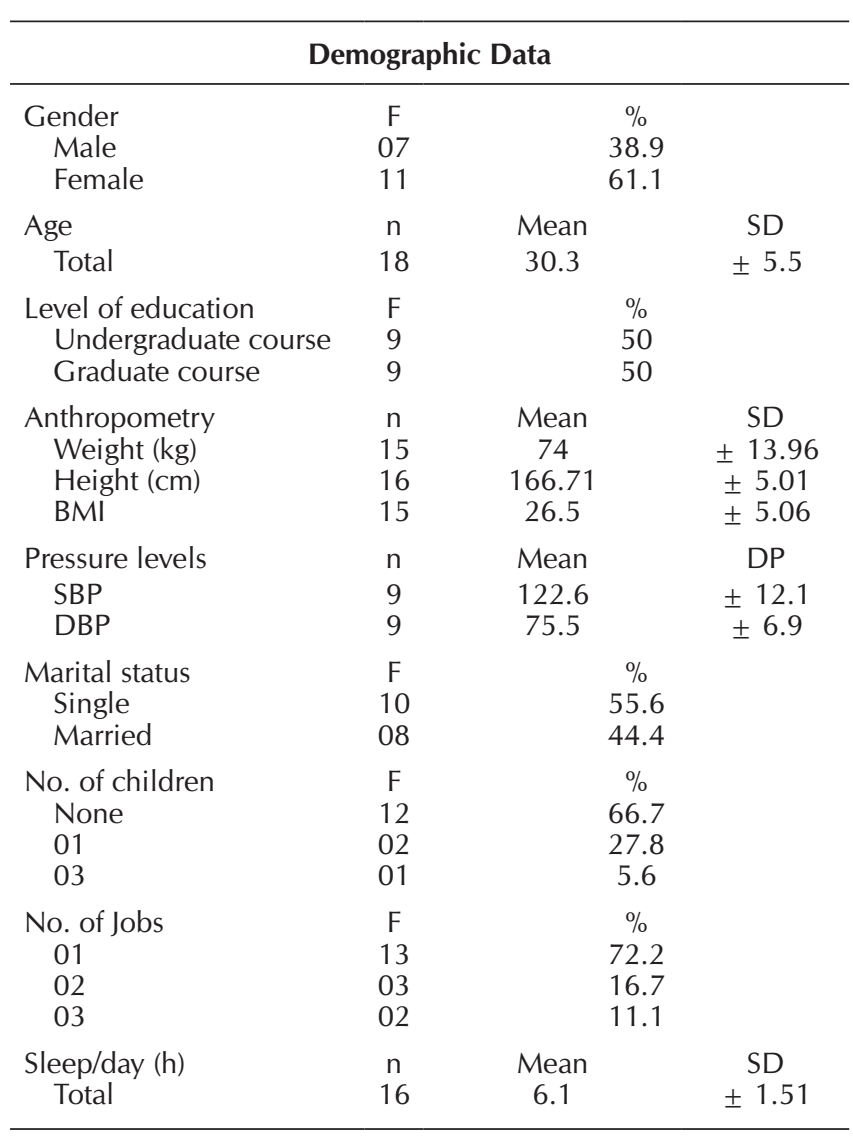

Note: BMI: body mass index; SBP: systolic blood pressure; DBP: diastolic blood pressure; $S D$ : standard deviation.

\section{Cognitive Testing - Trail Making Test $A$ and $B$}

The Shapiro-Wilk and Kolmogorov-Smirnov (KS) tests showed that the data did not have a normal distribution. Thus, the Wilcoxon test was used to compare the observation points (M0- beginning of the 24-hour shift and M2-end of the 24hour shift for Trail A and B), which showed that there was no relevant difference between the times observed ( $p>5 \%)$.

Table 2 - Time and Error in the Trail Making Test, Beginning and End of 24-hour Shifts, Nurses, Intensive Care Unit, Rio de Janeiro, Brazil, 2013

\begin{tabular}{ccccc}
\hline & \multicolumn{3}{c}{ Time in the Trail Making Test } \\
\hline \multicolumn{4}{c}{ Trail A } & \multicolumn{2}{c}{ Trail B } \\
\hline Time (s) & Mean (SD) & Median (IQR) & Mean (DP) & Median (IQR) \\
\hline M0 & $34.6(4.9)$ & $35(29.2-38.7)$ & $64.3(16.7)$ & $63.5(52.3-74.7)$ \\
M2 & $38.7(10.4)$ & $37(31.8-43.2)$ & $67.8(23.8)$ & $64.5(30.5-98.5)$ \\
\hline \multicolumn{4}{c}{ Error in the Trail Making Test } \\
\hline \multicolumn{4}{c}{ Trail A } \\
\hline Error & Mean (SD) & Median (IQR) & Mean (SD) & Median (IQR) \\
\hline M0 & $0.13(0.3)$ & $0(0)$ & $0.9(1.5)$ & $0.5(0-1.0)$ \\
M2 & $0.75(1.0)$ & $0(0-2.0)$ & $1.3(1.6)$ & $1.0(0-1.0)$ \\
\hline
\end{tabular}

Note: SD: standard deviation; IQR: interquartile range; MO: beginning of 24 hour shift; M2: end of 24-hour shift. 


\section{TAVIS 4.0}

Only 13 subjects were analyzed in this test. The loss of five $(27 \%)$ nurses was due to two reasons: 1$)$ delay in getting the software to start the tests; and (2) the withdrawal of some individuals from performing the 24-hour shift without informing the investigators. In this latter case, the participants only performed 12 hours on call, so there were no comparative data. It is noteworthy that, even though there was no participation in the final stage of the study, it was possible to obtain IQ, LISS, STAI, and BDI.

TAVIS results were not only quantitative but also qualitative. Signs of distraction, irritability, and distrust with the test were presented by the study participants, mainly in the M2 stage. One participant, after the 24-hour shift, fell asleep at about the eighth minute of the TAVIS 4.0 test, which lasts approximately 10 minutes.

The Shapiro-Wilk KS tests showed that the data for time, omission error, and action error did not present a normal distribution. Thus, data were analyzed by the Wilcoxon test, in which the results obtained for time $(p=0.068)$, omission errors $(p=0.088)$, and action errors $(p=0.409)$ were higher than $5 \%$. Thus, it is concluded that the difference between the times, omission errors, and action errors possibly do not interfere with the nursing capacity.

\section{LIPP Inventory of Stress Symptoms for Adults}

Among the 18 nurses investigated, $61 \%(n=11)$ presented a positive diagnosis for stress. The remaining 33\% $(n=6)$ presented the symptoms of stress, but lower than the limits established by LIPP(6). Of those who presented a positive diagnosis for stress, $45 \%(n=5)$ had scores above the limits in more than one condition. Only one participant (5.5\%) did not evidence any of the stress symptoms.

As for those with stress, $100 \%$ were in the resistance phase; in $73 \%$ there was a predominance of psychological symptoms ( $\mathrm{n}=8$ ). In $18 \%$, there was a predominance of physical symptoms $(n=2)$. In $9 \%(n=1)$, the percentage between physical and psychological symptoms was similar. In this case the individual has a tendency to have symptoms in both areas.

\section{Depression Inventory}

Data found in the sample for the18 participants.

Table 3 - Participants with Symptoms of Depression, Nurses, Intensive Care Unit, Rio de Janeiro/RJ/Brazil, 2013

\begin{tabular}{cccc}
\hline Score & Depressive picture & $\mathbf{n}$ & $\mathbf{\%}$ \\
\hline $0-9$ & Absent & 12 & 66.6 \\
$10-18$ & Mild to moderate & 01 & 5.5 \\
$19-29$ & Moderate to severe & 05 & 27.7 \\
$30-63$ & Severe & - & - \\
\hline
\end{tabular}

Note: N: number of participants; \%: percentage relation.

Most of the nurses evaluated in this study do not have obvious signs of depressive states; however, approximately $33 \%$ of those evaluated presented minimally worrying signs that could be elevated to a higher status of depression.

\section{Anxiety Inventory}

The table below presents a summary of the data found in our sample for the 18 subjects for both parts.

Table 4 - State-Anxiety Inventory, Nurses, Intensive Care Unit, Rio de Janeiro, Brazil, 2013

\begin{tabular}{cccc}
\hline Score & Level of anxiety & $\mathbf{n}$ & $\mathbf{\%}$ \\
\hline $20-34$ & Low & 03 & 16.6 \\
$35-49$ & Moderate & 11 & 61.1 \\
$50-64$ & High & 04 & 22.2 \\
$65-80$ & Very high & - & - \\
\hline
\end{tabular}

Note: N: number of participants; \%: percentage relation.

Table 5 - State-Trait Anxiety Inventory, Nurses, Intensive Care Unit, Rio de Janeiro, Brazil, 2013

\begin{tabular}{cccc}
\hline Score & Level of anxiety & $\mathbf{n}$ & $\mathbf{\%}$ \\
\hline $20-34$ & Low & 06 & 33.3 \\
$35-49$ & Moderate & 09 & 50.0 \\
$50-64$ & High & 03 & 16.6 \\
$65-80$ & Very high & - & - \\
\hline
\end{tabular}

Note: N: number of participants; \%: percentage relation.

With the result of the two scales of the Anxiety Inventory, State and Trait, it is observed that a level of moderate anxiety is the most evident. In the assessment of state-anxiety, nurses may present feelings of tension or apprehension, as a consequence of increased autonomic nervous system activity. In the evaluation of anxiety-trait, nurses may have different perceptions of anxiety reacting in different ways in each stress situation.

\section{DISCUSSION}

\section{About the demographic data}

Regarding the age of the population investigated, the average was 30.3 years. This is consistent with the data provided by the Federal Nursing Council following the analysis done in its database in 2011, which showed that most nursing professionals are in the age group of 25-35 years, which concentrates around $36 \%$ of nurses in Brazil ${ }^{(12)}$.

Regarding the distribution by gender, the number of women $(61.1 \%)$ predominated. This can be explained by the history of nursing in Brazil and in the world, which experienced intense feminization from the institutionalization of modern nursing beginning at the end of the nineteenth century. These data are also consistent with the data presented by the Federal Nursing Council in 2011, which attribute $87.35 \%$ to female workers in this occupation ${ }^{(12)}$.

An equivalent number was evident among undergraduate nurses (50\%) and those who are graduated (50\%). We emphasize that graduation refers only to lato sensu form. The evidenced data resemble those in the literature that show a predominance 
of the degree of specialist and PhD for female nurses, and undergraduate and master degrees for men ${ }^{(13)}$.

BMI showed that individuals ranged from normal weight to obesity according to criteria established by the World Health Organization (WHO). It is indicated that individuals with values equal to or greater than 30 are obese, and those whose BMI is equal to or greater than 25 are considered overweight ${ }^{(14)}$.

On the other hand, data from this study indicate the predominance of professionals who work in only one job $(72 \%)$. Regarding the hours of sleep, there was an average of $6.1 \pm 1.51$ hours per day.

\section{About stress, anxiety, and depression}

The study did not identify stressed individuals in the more advanced stages (near-exhaustion and exhaustion), but in the phases of alertness and resistance, with a predominance of the latter. The presence of individuals at this stage of stress is consistent with other studies that use other methods of stress diagnosis (2-3,7-9) $^{(2 .}$

A significant correlation between stress and depression ( $\rho=$ 0.564 with $p<0.05)$ and between stress and anxiety $(\rho=0.564$ with $p<0.05$ ) was observed in the study sample when a correlation between stress and anxiety was established (non-parametric Spearman $-\rho)$.

In addition to pathologies that may arise from psychological disturbances, physical disorders are common in nursing workers ${ }^{(8)}$.

A study of the levels of anxiety and depression in nurses working in shifts revealed that $92 \%$ presented with anxiety, with a predominance of a moderate level of anxiety. Another $60 \%$ of the sample had depression, and the median levels were present in $60 \%{ }^{(15)}$. These data are in contradiction to those found in this study, in which most subjects $(66.6 \%)$ do not present symptoms of depression.

The nurses that we evaluated worked, mandatorily, on a 24-hour shift; however, this is not a permanent shift in the unit, and is occasionally performed by nursing professionals. Among those investigated, $94.5 \%$ were on day shifts, which corroborates with another study ${ }^{(7)}$ regarding moderate levels of Trait and State anxiety for nurses who work in these shifts.

\section{About cognitive testing}

The results of the neuropsychological tests are consistent with those described in the literature. Some aspects of behavior were worse when facing the situation of undergoing a test than in the performance itself. The literature shows that patients with brain lesions are likely to show short-term attention, distraction, impulsivity, disorganization, irritability, perplexity, and distrust. Patients suffering stress effects may also behave similarly to subjects with brain deterioration ${ }^{(11)}$.

When the result found in the Trail Making Test is compared to the reference values described in the literature for the normal adult population, it is noticed that the times are above those described. This suggests that the sample already presents attentional dysfunctions ${ }^{(11)}$.

When establishing the correlation between stress and the times obtained in Trail Making Test A and B, it can be observed that for Trail A test there is a weak correlation between stress and task execution time in $\mathrm{M} 2(\rho=0.055)$, a fact that does not occur in $\mathrm{MO}(\rho=-0.249)$.

Regarding Trail Making Test B, when establishing a correlation between stress and the execution time of the task in M0 ( $\rho=$ $-0.314)$ and $M 2(\rho=-0,150)$, it can be observed that there was a negative correlation between the times. Thus, it can be inferred that stress does not influence nurses' cognitive flexibility.

Studies on the cognitive performance of adults with Attention Deficit Hyperactivity Disorder (ADHD) revealed that the participants presented with complaints of inattention. Although the methodology and population of this study is different from the one used, the neuropsychological test applied to the adults in the control group showed that the attention, memory, visualmotor dexterity and cognitive flexibility tests were not altered in those with complaints of attention deficit ${ }^{(5,16)}$.

People with lower ages and higher education levels showed better performance in attentional tasks, which suggests the influence of these variables on the attention process. These data confirm what was obtained, but we cannot infer that education level influences the attentional tests ${ }^{(16)}$.

The fact that stress is predominant in the resistance phase suggests that the cognitive processes investigated have undergone little variation in the proposed times. Research is still controversial in its conclusions, because it shows that stress sometimes increases the level of attention and sometimes reduces $i t^{(3,16)}$. An experimental study found that stress impairs the attention process due to the increase in the amount of irrelevant information ${ }^{(3)}$.

The series of tests used was applied in a reserved environment, away from external interference, but the macro-environment of care still remained as a stressor. Laboratory measurements do not always represent the actual demands of life (ecological validity). Therefore, it is necessary to consider the complaints and the behavior presented during testing application ${ }^{(11)}$.

This is a study focused on the impact of stress on work, and the cognitive influence on hospital safety incidents (all types of errors) ${ }^{(17)}$, and it helps to illustrate these research findings. The sample consists of 279 Korean nurses who worked in direct patient care in five different hospitals. It was concluded that the factors that most interfere with client safety are work shift $(O R=6.85)$ and cognitive insufficiency $(O R=2.92)$. It should be noted that the cognitive analysis tool used in this study also evaluated the processes of attention and memory.

Studies define the following as situations indicating attention deficits: conversations in which the subjects frequently request that the questions or instructions of the tests be repeated (inattention); when there is frequent interruption on the part of the interlocutor (impulsivity); or when the examinee is informally performing two tasks (speaking with the examiner and performing the selected tasks) $)^{(5,18-20)}$.

It is worth mentioning that the participants in this study, after 24 hours of work, initiated dialogues with the researcher on issues that were different from the subject, and showed apparent uneasiness when performing the series of tests for the second time, specifically motor agitation of the lower limbs. It was evident that not all of the professionals had the concentration for the tests when performing the tests after a 24-hour shift. 
Prolonged work demanding high concentration, which is interrupted at all times by factors that cause indecision (questioning) when being carried out, results in a compensatory effort. This is related to the extra effort expended, in the case of nurses, when performing their actions under adverse conditions. A greater mental cost is necessary to maintain optimal cognitive conditions ${ }^{(20-22)}$.

Depression and stress favor hypoprosexia. There is a tendency to loss of concentration, comprehension, and difficulty of perception about environmental stimuli. There may be some difficulties in developing complex psychic activities such as thinking, reasoning, and information organization ${ }^{(19,23)}$.

Our results are consistent with the understanding of the speed-precision conflict. Studies reveal that this term addresses the inversely proportional relationship between speed and movement precision. In this case, with increasing speed, the spatial accuracy decreases and, conversely, improved precision results in a decrease in speed ${ }^{(23-24)}$.

The Trail Making Test helps in the evaluation of sustained and alternated attention, as well as of the individual's motor function. The accounting of errors was made from the third error made by nurses, as described in some studies ${ }^{(1,23,25)}$.

It is worth noting that, in M2, the time of performance in Trail Making Test B presents variability and a greater asymmetry. Regarding errors, even if within the expected, their increase suggests that the subjects' cognitive flexibility is declining ${ }^{(19)}$.

When we evaluate this situation for the nursing field, it is inferred that the process of work in ICUs, which is extremely dynamic, undergoes a decline after 24 hours.

For the nursing team, this may mean minimizing a job that is rich in details. Simplifying an event can bring about irreversible problems. In this study, two problems are observed. The first relates to the mitigation of the effects that a 24-hour work shift and extensive workloads cause in cognitive processes such as attention/concentration, memory, and psychomotor ability. The second is the effect they have on the nurse's caregiving action.

\section{Study limitations}

This study does not intend to cover every aspect of the theme. However, it opens perspectives for the expansion of new investigations about the physical, mental, and emotional exhaustion to which the nurses are exposed after 24-hour shifts in intensive care units, even being susceptible to the risks of making errors when caring for clients admitted to these units.

Contribution to the nursing, health, and public policies areas

The study contributes to the planning of nursing care in intensive care units, considering that its results correlate the elevation of stress levels, decrease in attention process, and psychomotor decline of nurses working in 24-hour schedules.

\section{CONCLUSION}

The sample revealed the presence of stress in $61 \%$ of the nurses, with predominance in the resistance phase and psychological symptoms, according to the inventory used. Of these, $45 \%$ presented gross scores above the limits in more than one phase of stress, which leads to the risk of change to more harmful phases of stress. About 33\% of the participants had symptoms of depression, and about $99.9 \%$ showed symptoms of anxiety, with $22 \%$ achieving high levels of anxietystate, and $16.6 \%$ of anxiety-trait.

There was a full correlation between stress and anxiety, and a substantial correlation for stress and depression ( $p<0.005)$.

The times individuals took to perform the test both at the beginning of the shift and after 24 hours of work are above those found in the literature for a theoretically normal population. However, there was no correlation between stress and achievement times of either Trail A and Trail B. Nurses showed some level of inattention but showed less impulsivity when compared at the beginning and end of a 24-hour shift.

Regarding psychomotor functioning, the individuals presented the speed-precision conflict which is typical of psychomotor decline.

The results of this study point us to new research in the same area. However, it is necessary to consider important variables that have not been controlled for from the beginning, which may have generated confusion, such as the nurses' rest periods during the 24-hour shift.

\section{REFERENCES}

1. Faria CA, Alves HVD, Charchat-Fichman H. The most frequently used tests for assessing executive functions in aging. Dement Neuropsychol[Internet]. 2015[cited 2015 Oct 12];9(2):149-55. Available from: http://www.scielo.br/pdf/dn/v9n2/1980-5764dn-09-02-00149.pdf

2. Kakushi LE, Evora YDM. Direct and indirect nursing care time in an Intensive Care Unit. Rev Latino-Am Enferm [Internet]. 2014[cited 2015 Oct 16];22(1):150-7. Available from: http://www.scielo.br/pdf/rlae/v22n1/0104-1169-rlae-22-01-00150.pdf

3. Monte PF, Lima FET, Neves FMO, Studart RMB, Dantas RT. Stress among professional nurses working in intensive care units. Acta Paul Enferm [Internet]. 2013[cited 2015 Oct 08];26(5):421-7. Available from: http://www.scielo.br/pdf/ape/v26n5/en_a04v26n5.pdf

4. Ulas T, Buyukhatipoglu H, Kirhan I, Dal MS, Ulas S, Demir ME, et al. Evaluation of oxidative stress parameters and metabolic activities of nurses working day and night shifts. Rev Esc Enferm USP [Internet]. 2013[cited 2015 Sep 18];47(2):471-6. Available from: http://www.scielo.br/pdf/reeusp/v47n2/28.pdf

5. Rodrigues VMCP, Ferreira ASS. Stressors in nurses working in Intensive Care Units. Rev Latino-Am Enferm[Internet]. 2011 [cited 2015 Sep 27];9(4):1025-32. Available from: http://www.scielo.br/pdf/rlae/v19n4/23.pdf

6. Martins MGT, Castro O, Pereira PPG. Body, stress and nursing: ethnography of an Intensive Care and Surgical Center. Estud 
Psicol[Internet]. 2013[cited 2015 Sep 18];30(4):525-37 Available from: http://www.scielo.br/pdf/estpsi/v30n4/06.pdf

7. Panunto MR, Guirardello EB. Nursing workload in an intensive care unit of a teaching hospital. Acta Paul Enferm[Internet]. 2012[cited 2015 Sep 21];25(1):96-101. Available from: http://www.scielo.br/pdf/ape/v25n1/en_v25n1a17.pdf

8. Carmona-Monge FJ, Uranga IU, Gómez SG, Herranz CQ, Bengoetxea MB, Unanue GE, et al. Usage analysis of the Nursing Activities Score in two Spanish ICUS. Rev Esc Enferm USP[Internet]. 2013[cited 2015 Sep 21];47(5):1106-13. Available from: http://www.scielo.br/pdf/reeusp/v47n5/0080-6234-reeusp-47-05-1106.pdf

9. Montanholi LL, Merighi MAB, Jesus MCP. The role of the nurse in the neonatal intensive care unit: between the ideal, the real and the possible. Rev Latino-Am Enferm[Internet]. 2011[cited 2015 Oct 09];19(2):301-8. Available from: http://www.scielo.br/ $\mathrm{pdf} / \mathrm{rlae} / \mathrm{v} 19 \mathrm{n} 2 / 11 . \mathrm{pdf}$

10. Freitas AR, Carneseca EC, Paiva CE, Paiva BSR. Impact of a physical activity program on the anxiety, depression, occupational stress and burnout syndrome of nursing professionals. Rev Latino-Am Enferm [Internet]. 2014[cited 2015 Sep 09];22(2):332-6. Available from: http://www.scielo.br/pdf/rlae/v22n2/0104-1169-rlae-22-02-00332.pdf

11. Passos VMA, Caramelli P, Benseñor I, Giatti L, Sandhi MB. Methods of cognitive function investigation in the Longitudinal Study on Adult Health (ELSA-Brasil). São Paulo Med J[Internet]. 2014[cited 2015 Aug 26];132(3):170-7. Available from: http://www. scielo.br/pdf/spmj/v132n3/1516-3180-spmj-1516-3180-2014-1323646.pdf

12. Barreto IS, Krempel MC, Humerez DC. O COFEN e a Enfermagem na América Latina. Enferm Foco[Internet]. 2011 [cited 2015 Oct 14];2(4):251-54. Available from: http://revista.portalcofen.gov.br/index.php/enfermagem/article/viewFile/195/131

13. Griep RH, Fonseca MJM, Melo ECP, Portela LF, Rotenberg L. Nurses of large public hospitals in Rio de Janeiro: socio demographic and work related characteristics. Rev Bras Enferm [Internet]. 2013[cited 2015 Aug 19];66(n.spe):151-7. Available from: http:// www.scielo.br/pdf/reben/v66nspe/v66nspea19.pdf

14. World Health Organization (WHO). Obesity[Internet]. Geneva (CH): WHO; 2014 [cited 2015 Aug 20]. Available from: http:// www.who.int/topics/obesity/en/

15. Oliveira V, Pereira T. Ansiedade, depressão e burnout em enfermeiros: impacto do trabalho por turnos. Referência[Internet]. 2012[cited 2015 Aug 09];serlII(7):43-54. Available from: http://www.scielo.gpeari.mctes.pt/pdf/ref/vserllln7/serllln7a05.pdf

16. Menezes A, Dias NM, Trevisan BT, Carreiro LRR, Seabra AG. Intervention for executive functions in attention deficit and hyperactivity disorder. Arq Neuro-Psiquiatr[Internet]. 2015[cited 2015 Aug 09];73(3):227-36. Available from: http://www.scielo. br/pdf/anp/v73n3/0004-282X-anp-73-3-0227.pdf

17. Park YM, Kim SY. Impacts of job stress and cognitive failure on patient safety incidents among hospital nurses. Saf Health Work[Internet]. 2013[cited 2015 Oct 21];4(4):210-15. Available from: https://www.ncbi.nlm.nih.gov/pmc/articles/PMC3889080/ $\mathrm{pdf} / \mathrm{main} . \mathrm{pdf}$

18. Campos JF, David HSL. Work context assessment in intensive therapy units from the perspective of work psychodynamics. Rev Esc Enferm USP[Internet]. 2011[cited 2015 Aug 16];45(2):363-8. Available from: http://www.scielo.br/pdf/reeusp/v45n2/en v45n2a08.pdf

19. Schmidt DRC, Paladini M, Biato C, Pais JD, Oliveira AR. Quality of working life and burnout among nursing staff in Intensive Care Units. Rev Bras Enferm[Internet]. 2013[cited 2015 Sep 02];66(1):13-7. Available from: http://www.scielo.br/pdf/reben/v66n1/ v66n1a02.pdf

20. Elfering AS, Grebner S, Duran A. Job characteristics in nursing and cognitive failure at work. Saf Health Work[Internet]. 2011[cited 2015 Sep 02];2(2):194-200. Available from: https:/www.ncbi.nlm.nih.gov/pmc/articles/PMC3431903/pdf/shaw-2-194.pdf

21. Camelo SHH. Professional competences of nurse to work in Intensive Care Units: an integrative review. Rev Latino-Am Enferm[Internet]. 2012[cited 2015 Aug 14];20(1):192-200. Available from: http://www.scielo.br/pdf/rlae/v20n1/25.pdf

22. Nogueira LS, Koike KM, Sardinha DS, Padilha KG, Sousa RMC. Nursing workload in public and private intensive care units. Rev Bras Ter Intensiva[Internet]. 2013[cited 2015 Aug 14];25(3):225-32. Available from: http://www.scielo.br/pdf/rbti/v25n3/en_0103507x-rbti-25-03-0225.pdf

23. Novaretti MCZ, Santos EV, Quiterio LM, Daud-Gallotti RM. Nursing workload and occurrence of incidents and adverse events in ICU patients. Rev Bras Enferm[Internet]. 2014[cited 2015 Sep 21];67(5):692-9. Available from: http://www.scielo.br/pdf/reben/ v67n5/0034-7167-reben-67-05-0692.pdf

24. Pereira FMV, Malaguti-Toffano SE, Silva AM, Canini SRMS, Gir E. Adherence to standard precautions of nurses working in intensive care at a university hospital. Rev Esc Enferm USP[Internet]. 2013[cited 2015 Aug 22];47(3):686-93. Available from: http://www. scielo.br/pdf/reeusp/v47n3/en_0080-6234-reeusp-47-3-00686.pdf

25. Lobao WM, Menezes IG. Psychometric analysis of the scale for the predisposition to the occurrence of adverse events in nursing care provided in ICUS. Rev Latino-Am Enferm[Internet]. 2013[cited 2015 Aug 22];21(1):396-403. Available from: http://www. scielo.br/pdf/rlae/v21n1/v21n1a15.pdf 